\title{
Walking Methodologies with/in Teacher Education
}

\author{
Asilia Franklin-Phipps ${ }^{1}$ and Tristan Gleason ${ }^{2}$ \\ ${ }^{1}$ The Graduate Center, CUNY, New York and ${ }^{2}$ Moravian College, Bethlehem The United \\ States of America
}

\begin{abstract}
This essay begins with the limitations of reflection in teacher education practitioner research. We wonder about the confines of a reflective practice that is solitary, ahistorical, and written in a particular academic register with an audience of one in mind. Instead, we explore the potential of walking methodologies as critical praxes with a group of pre-service educators. To do so we take a walk that is collective and focused on the way history is entangled with the students' multimodal responses to this experience. We argue that walking as reflective praxis produces different possibilities in the space of teacher education. Pre-service educators participated in a mode of public pedagogy that challenges the treatment of teaching and learning as ahistorical and universal processes that can be neatly represented by the written word.
\end{abstract}

\section{Key Words}

Praxis; teacher education; race, pedagogy 
The purpose of this short essay is to inquire into the role walking methodologies (Springgay \& Truman, 2018) might play in teacher education, particularly teacher education aimed at critical and creative pedagogies and praxes. We are teacher educators who developed our praxis, along with our friendship, as doctoral students on the West Coast of the United States. We now continue this work at separate institutions in the North East. We are differently positioned across the categories of gender, race, and sexuality, and walk and think together about developing approaches to teacher education that might matter in our precarious political present. Teacher education, at its best, seeks to prepare practitioner-researchers (e.g. Cochran-Smith \& Lytle, 2009; Zeichner \& Liston, 2014).

This approach to teacher education recognizes that classrooms are distinct spaces, shaped by the political, social and historical. Teachers, accordingly, need to become researchers of both their practice and the environments in which their practice is embedded and entangled. This broad framework for teacher education has played an important role in resisting the forces of neoliberalism, which position teachers as technicians or unskilled laborers (Ravitch, 2013). At the same time, we argue that the research methods that inform teacher education have not responded to the recent proliferation of educational methodologies, from posthumanism (Snaza \& Weaver, 2015) to the ontological turn (Lather, 2016; Zembylas, 2017) and new materialisms (Alaimo, 2010; Kirby, 2011). About teacher education, Esther Ohito writes that, "even with a genesis in critical theory, it has been my experience that these pedagogies reinforce the Eurocentric, Cartesian mind-body dualism residing at the center of White supremacy by privileging cognitive comprehension over embodied knowing" (Ohito, 2016 , p. 456). In our combined sixteen years working in teacher education, we have also found these limits to be an ongoing constraint.

\section{Problematizing Reflection in Teacher Education}

One of the most ubiquitous research-turned-pedagogical practices in teacher education is the act of reflection through writing. Preservice teachers are asked to write reflectively in response to a wide range of activities, from engaging texts and observing educational spaces, to the preparation and delivery of lessons. Such writing is almost always done in private, and often for an audience of one- the course instructor - and frames classroom practices as ahistorical. This approach reduces the complexity of practitioners experiencing, sensing, and thinking to their competence with the written word. The limitations of reflection have been addressed by feminist scholars of science (e.g. Barad, 2007) and teacher educators alike (Fendler, 2003). Following such thinkers, reflection, as commonly practiced and understood, is just as likely to confirm and sediment our interpretative habits, as it is to change them, emphasizing sameness rather than fluidity. At the same time, these critiques have done little to disrupt reflection in practice. Teacher educators, including us, continue to hope that the act of reflection enables pre-service and practicing teachers to better understand and know the diverse array of phenomena that matter in educational spaces. In particular, we want to draw attention to how the traditional practice of reflection aims at producing a particular positionality, one inspired by traditions like phenomenology and critical theory, which purportedly enables individual subjects to become objective, to see through the fog of false consciousness, and to obtain what Haraway (1988) has called the "god trick" (p. 538) of omniscient and transcendent vision.

Instead of directing our efforts in classrooms towards the production of specific and stable positionalities, what if we participated in the proliferation of different research praxes within teacher education? Imani Perry (2018) engenders this question when she asks us to understand feminism as a critical practice, rather than "a set of positions or doctrines" (p. 6). 
To that extent, we are interested in developing methodologies in teacher practitioner research that produce different educational possibilities and enable the reconstruction of subject positions that are collective, uncertain, embodied and differently attuned to diverse assemblages of human and non-human agents.

\section{The Ecologies of the Bethlehem SteelStacks}

This historico-critical attitude must also be an experimental one. I mean that this work done at the limits of ourselves must, on the one hand, open up a realm of historical inquiry and, on the other, put itself to the test of reality, of contemporary reality, both to grasp the points where change is possible and desirable, and to determine the precise form this change should take.

(Foucault, 2010, p.46)

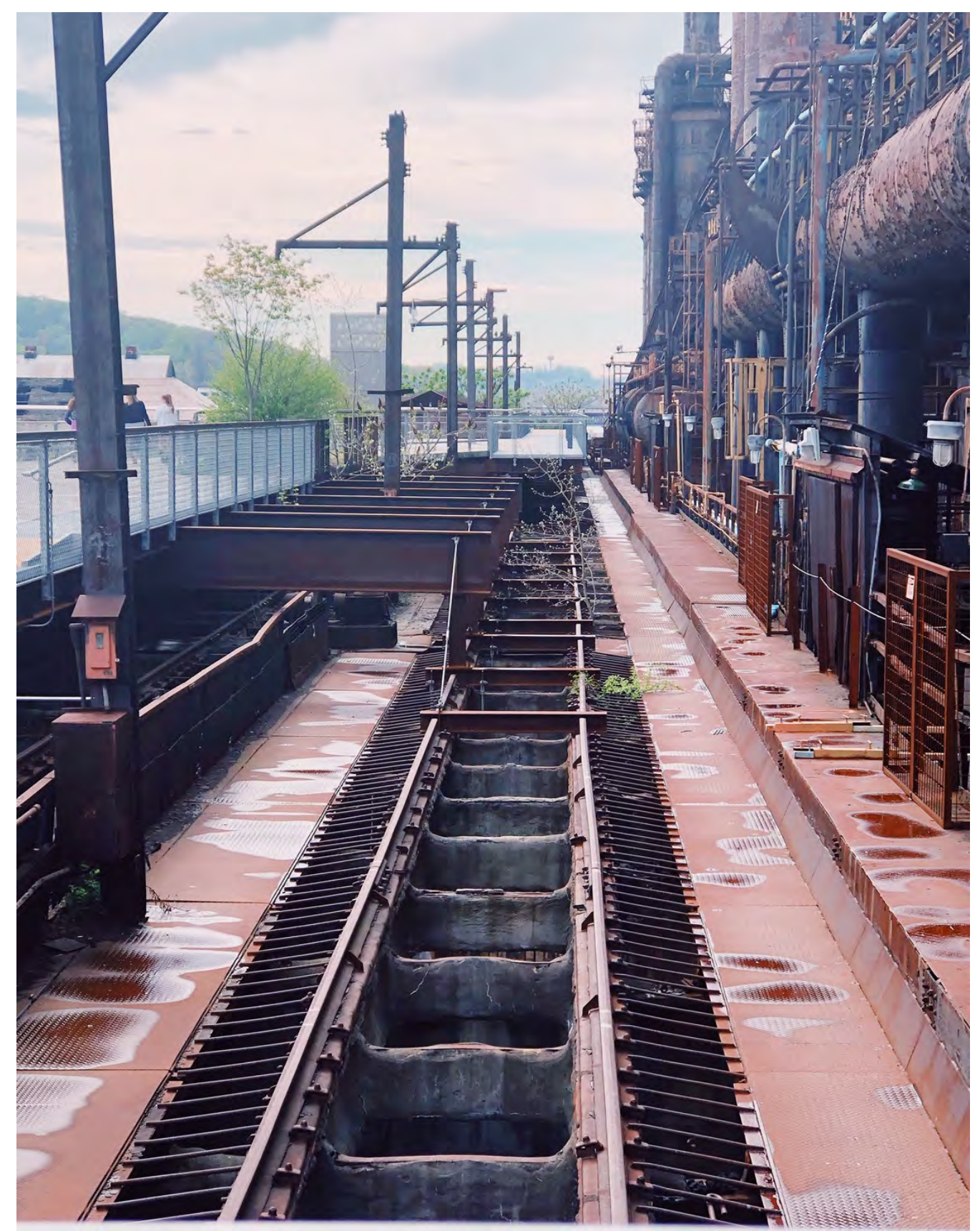

Figure 1: Bethlehem, Pennsylvania SteelStacks. Photo credit: Asilia Franklin-Phipps 
Drawing inspiration from Foucault's description of a methodology that is both historicocritical and experimental, Tristan developed a short project with a group of pre-service educators who were completing their final semester of a certification program at a small liberal arts college in Eastern Pennsylvania. Eleven students, all seeking certification in middle level and secondary content areas, attended a seminar with Tristan once a week in addition to their work as full-time student teachers. Eight of the preservice teachers identify as women and three as men. Seven are white and three are Latinx and Black; Tristan is white and Asilia, who joined the seminar for the walk, is Black. The project aimed to encourage students to consider how the history and present circumstances of land and geography matter to their process of becoming educators by having them walk through and think with the remnants of the Bethlehem SteelStacks. The Bethlehem SteelStacks is a huge steel processing plant that dominated the economic livelihood of the community from the late 1800's until the plant closed in the 1990's. Bethlehem Steel is inseparable from the project of industrialization across the United States, and the social, demographic and environmental effects imbricated with this history. Moreover, this land continues to shape the present; today, the SteelStacks house a casino and a movie theater, host concerts and events throughout the year, and has developed an unanticipated economic relationship with elderly, primarily Chinese, immigrant populations who reside near New York City and, in the words of a local newspaper article, "ride [the] bus to live" (Assad \& Lehman, 2014). As an incentive to travel and gamble, Bethlehem casinos offer a 45-dollar free-play card, which the riders can then sell. Once they have exchanged their vouchers for cash, they must wait five hours at the SteelStacks before returning home. These bus riders understand it as a job.

\section{Walking with Ghosts}

On the day of the field trip, Asilia joined Tristan to participate in this walking exercise. The project asked students to take pictures, record sounds and conversations, and jot down other ideas and notes that came to them during their walk. After the walk, students constructed multi-modal responses to the experience and shared these with each other on a blog site created for the purpose.

We arrived before the students in the class, Tristan with a tote bag of clipboards borrowed from a colleague, and Asilia, with a notebook and a polaroid camera. From an instructional perspective, it feels important to contrast this curricular space with that of the classroom. While instructors might imagine an outsized influence over what happens in a classroom, the SteelStacks precluded any notions of meaningfully managing how students would engage or learn in the space, and, how the walking/thinking/learning resisted being imagined in advance. Although we wanted to help these students think about the importance of place, neither of us felt able to teach about the history of a place we did not know. Instead, our focus was on the haptic experience of walking together through this place as a means to begin to learn, not only about place but about our inter-dependency with place and each other.

After a quick meet-up, we walked toward the far entrance of an elevated walkway that meanders the length of the old steel production facility. The walkway was designed by the same architects who constructed the Highline in New York City, and the decorative plants and informational signs stand in stark contrast to the rusted structures that once produced much of the United State's steel. On our way toward the entrance, we walked past a playground. A group of older people sat speaking Chinese and eating lunch, spread out along a series of metal benches. Another group practiced Tai Chi with the sound of gentle music 
playing in the background. Once past the entrance, visitors are led up a flight of stairs overlooking what once was one of the main areas of steel production, ghostly now in the absence of workers whose pictures on informational placards haunt the path.

During the walk, students walked alongside tourists taking selfies - all with the imposing structure in the background. They paused to read the information written on signs, noticed orange peels stuffed into the fence and littered along the plants growing into the decaying steel plant. They asked each other questions and noticed things together. They shared anecdotes and prior connections to the place, making vibrations with the difference of memory. They talked and worked to document aspects of the once-industrial space that demanded their attention. The content of their experiences is beyond the scope of this essay, and we invite readers to explore along with these students by accessing the work they created at the following web address:

https://steelstackswalkingtoteach.home.blog.

\section{Re-Imagining Reflection}

We are enthusiastic about the potential of walking methodologies to disrupt the ahistorical, private, and writing-centric nature of reflective praxes in teacher education. Although this walking method happened outside of the classroom, this is not what makes this practice a form of public pedagogy. Rather, we draw on the work of Gert Biesta (2012), who uses the term public pedagogy to refer to "the achievement of a form of human togetherness in which... action is possible, and freedom can appear" (p. 693). In addition, we believe this praxis works toward a notion of history that is informed by what Stacy Alaimo (2010) calls transcorporeality, or the "material interchanges between human bodies, geographical places, and vast networks of power" (p. 32). Importantly, this is a different notion of historicity than what accompanies more traditional critical approaches to education, which treat history as a teleological, linear and discursive construct (e.g. Freire, 2012). Instead, we think historicity with Frantz Fanon (1967/2008), who emphasizes invention over determinism, and Sylvia Wynter (2003), who demonstrates the necessity of simultaneously historicizing nature, culture, and the overdetermination of the human by Man. Further, walking methodologies are intimately related to research practices that question the privileging of writing and textual production over other modes of engaging with the world (Springgay \& Truman, 2018).

Finally, we end by suggesting that the relationship we imagine between teacher education and walking methodologies is one of mutualism, and, as in "all symbiosis, [this is] a relation between two heterogeneous ways of being, both needing the other because without the other none of them would be able to achieve its own pathways and goals" (Stengers, 2005, p. 190). It is within specific practices and habitats that we are best able to develop new methods for thinking, doing, and relating. 


\section{References}

Alaimo, S. (2010). Bodily natures: Science, environment, and the material self. Bloomington, IN: Indiana University Press.

Assad, M., \& Lehman, P. (2014). Asians at sands casino 'ride bus to live'. The Morning Call. Retrieved March 29 from: https://www.mcall.com/

Barad, K. (2007). Meeting the universe halfway: Quantum physics and the entanglement of Matter and Meaning. Durham, NC: Duke University Press.

Biesta, G. (2012). Becoming public: public pedagogy, citizenship, and the public sphere. Social \& Cultural Geography, 13 (7), 683-697. https://doi.org/10.1080/14649365.2012.723736

Cochran-Smith, M., \& Lytle, S. L. (2009). Inquiry as stance: Practitioner research for the next generation. New York, NY: Teachers College Press.

Fanon, F. (2008). Black skin, white masks (Translated by C. L. Markmann Trans. ). New York, NY: Grove Press. Originally published 1967.

Fendler, L. (2003). Teacher reflection in a hall of mirrors: Historical influences and political reverberations. Educational Researcher, 32(16), 17-25.

Foucault, M. (2010). What is enlightenment? In Rabinow, P., Ed. The Foucault Reader. New York, NY: Vintage Press.

Freire, P. (2012). Pedagogy of the oppressed (30th anniversary ed.). New York, NY: Bloomsbury.

Haraway, D. (1988). Situated knowledges: The science question in feminism and the privilege of partial perspective. Feminist Studies, 14(3), 575-599.

Kirby, V. (2011). Quantum anthropologies: Life at large. Durham, NC: Duke University Press.

Lather, P. (2016). Top ten+ list: (Re)thinking ontology in (post)qualitative research. Cultural Studies $\leftrightarrow$ Critical Methodologies, 16(2), 125-131.

https://doi.org/10.1177/1532708616634734

Ohito, E. (2016). Making the emperor's new clothes visible in anti-racist teacher education: Enacting a pedagogy of discomfort with white preservice teachers. Equity \& Excellence in Education, 49(4), 454-467. https://doi.org/10.1080/10665684.2016.1226104

Perry, I. (2018). Vexy thing: On gender and liberation. Durham, NC: Duke University Press.

Ravitch, D. (2013). Reign of error: The hoax of the privatization movement and the danger to America's public schools. New York, NY: Vintage Books.

Snaza, N. (Ed.), \& Weaver, J. (Ed.). (2015). Posthumanism and educational research. New York, NY: Routledge.

Springgay, S. \& Truman, S. E. (2018). Walking and the more-than-human: WalkingLab. New York, NY: Routledge. 
Stengers, I. (2005). Introductory notes on an ecology of practices. Cultural Studies Review, 11(1), 183-196.

Wynter, S. (2003). Unsettling the coloniality of being/power/truth/freedom: Towards the human, after man, its overrepresentation-an argument. CR: The New Centennial Review,3(3), 257-337.

Zeichner, K.M., \& Liston, D.P. (2014). Reflective teaching, an introduction, second edition. New York, NY: Routledge.

Zembylas, M. (2017). The contribution of the ontological turn in education: Some methodological and political implications. Educational Philosophy and Theory, 49, 14011414. https://doi.org/10.1080/00131857.2017.1309636

Asilia Franklin-Phipps is a Lauder Postdoctoral Fellow at The Graduate Center of the City of the University of New York. Her work is interested in race, experimental pedagogies, affect, and the potential of arts practices in K-12, university, and teacher education.

Tristan Gleason is an assistant professor of education at Moravian College, and his work focuses on social justice, teacher education, science education, and post-qualitative research methodologies.

\footnotetext{
i See Haraway (1988) for her critique of an objectivity founded on the premise of disembodiment and omniscience
} 